\title{
Potential of Indigenous Enzymatic Activities, Nitric Oxide and Ceruloplasmin in Bovine Milk to Diagnose Subclinical Mastitis
}

\section{U.K De* and Reena Mukherjee}

Division of Medicine, Indian Veterinary Research Institute, Izatnagar-243122 (UP), India

\begin{abstract}
The objective of this present study was to evaluate some indigenous enzymatic activities, nitric oxide production in milk cells and ceruloplasmin $\left(\mathrm{C}_{\mathrm{p}}\right)$ level in milk as diagnostic indicators of bovine subclinical mastitis (SCM). The crossbred cows were screened with California mastitis test (CMT) to determine the status of SCM in mammary glands. Based on CMT point score and somatic cell count (SCC) of milk, the mammary quarters were classified as healthy (negative CMT reaction and SCC $<3$ lakhs $/ \mathrm{ml}$ ) and SCM (CMT reaction + or more and SCC $>10$ lakhs/ $\mathrm{ml}$ ). The results of the study revealed that SCC, cyclooxygenase (COX), myeloperoxidase (MPO), lactoperoxidase (LP), nitric oxide $(N O)$ and ceruloplasmin $\left(C_{p}\right)$ levels were significantly $(p<0.05)$ higher in milk collected from SCM quarters compared to healthy quarters. Pearson's correlation $(r)$ of paired data of individual SCM infected quarters revealed the existence of a significant positive $(P<0.01)$ correlation among SCC and COX activity, LP activity, MPO activity and NO production. However, no significant correlation between SCC and Cp level was observed in milk samples of SCM infected quarters. Therefore, alteration of these enzyme activities, NO production and $\mathrm{C}_{\mathrm{p}}$ activity in milk could be used as an alternative diagnostic tool to screen for SCM.
\end{abstract}

Keywords: Ceruloplasmin; Cyclooxygenase; Lactoperoxidase; Milk; Myeloperoxidase; Nitric oxide; Subclinical mastitis

\section{Introduction}

Bovine mastitis is an important animal health disease leading to significant economic losses to the dairy industry due to higher treatment cost and culling rate. Massive influx of somatic cells and secretion of inflammatory mediators into udder are the common features in intramammary infection [1]. During inflammation, lipid derived mediators such as prostaglandins are involved in mammary immunity which exerts potent chemokinetic and chemotactic activity on leukocytes [2]. Cyclooxygenase (COX), a key enzyme, plays a vital role in prostaglandin synthesis during inflammation. An increased synthesis of arachidonic acid metabolites and high concentration of COX are observed during mastitis [3].

Nitric oxide (NO), produced from L-arginine by nitric oxide synthase, controls various vital physiological functions of body and it is important in the host defense by destroying microbes. The antimicrobial effect of $\mathrm{NO}$ on bacteria is due to peroxynitrite, reactive nitrogen metabolite, derived from oxidation of NO. The macrophage and epithelial cells of mammary gland produce significant amount of nitric oxide that takes part in the inflammatory process [4]. Many workers reported that level of $\mathrm{NO}$ in mammary gland secretion increases significantly in subclinical and clinical mastitis [5-7].

The acute phase response is the reaction of animals to disturbance in its homeostasis caused by infection, tissue injury or immunological disorders $[8,9]$. High concentration of acute phase protein in milk from infected quarters has been detected due to high permeability of blood milk barrier during episodes of mastitis [10]. Ceruloplasmin $\left(\mathrm{C}_{\mathrm{p}}\right)$ is recognized as an important acute phase reactant in the cows and its high concentration has been observed in mastitis $[11,12]$.

Mastitis generally increases the enzymatic and biochemical activities in milk [13]. The myeloperoxidase (MPO), a lysosomal enzyme of neutrophilic granules, is a constituent of oxygen dependent antimicrobial activity of leukocytes [14]. MPO, along with hydrogen peroxide and halide creates potent oxygen dependent antimicrobial agent of the cell against pathogen [15]. Researcher observed increased level of MPO during mastitis where leukocyte function is activated $[16,17]$. Similarly, lactoperoxidase (LP) is the predominant enzyme in bovine milk responsible for its antimicrobial properties, which requires sufficient concentrations of hydrogen peroxide and thiocyanate ion. It is the second most abundant enzyme in bovine milk after xanthine oxidoreductase [18]. Andrei et al. [19] observed increased LP activity in mastitis milk.

Although, diagnosis of clinical mastitis by visual inspection and palpation is relatively easy but, diagnostic problems arise when dealing with subclinical mastitis where an increased somatic cell count (SCC) is the only finding. Further, SCM possess a potential health threat to other cows for new infection. Therefore, efficient detection of SCM is very much required to reduce the incidence of mastitis in a wellmanaged dairy herd. As per the recommendation of International Dairy Federation (IDF), the diagnosis of mastitis is based on the SCC and microbiological status of the quarter [20]. Bacteriological sampling is not always feasible as a routine test to identify subclinical mastitis as the procedure is both time consuming and uneconomical in large dairy herds. Presently, SCM is generally diagnosed by cow-side tests like the California Mastitis Test (CMT) or by SCC in milk samples. These tests are less efficient in detecting chronic subclinical mastitis than for acute clinical cases [21]. Therefore, it is important to investigate alternative parameters/methods for detection of SCM. Hence, the present study was conducted to evaluate certain indigenous enzymatic activities and $\mathrm{NO}$ production in milk cells and $\mathrm{C}_{\mathrm{p}}$ activity in milk as diagnostic indicators of bovine SCM.

*Corresponding author: U K De, Scientist, Division of Medicine, Indian Veterinary Research Institute, Izatnagar-243122 (UP), India, Tel : +91-581-230587,Fax: +91 581 2301940, E-mail: ujjwalde@gmail.com

Received May 12, 2011; Accepted August 25, 2011; Published October 30, 2011

Citation: De UK, Mukherjee R (2011) Potential of Indigenous Enzymatic Activities, Nitric Oxide and Ceruloplasmin in Bovine Milk to Diagnose Subclinical Mastitis. J Veterinar Sci Technol 2:109. doi:10.4172/2157-7579.1000109

Copyright: (c) 2011 De UK, et al. This is an open-access article distributed under the terms of the Creative Commons Attribution License, which permits unrestricted use, distribution, and reproduction in any medium, provided the original author and source are credited. 


\section{Materials and Methods}

\section{Selection of animals and collection of milk samples}

The present study was conducted in a livestock research farm (Cattle \& Buffalo) of the institute. These crossbred cows were maintained in the animal shed of the institute under identical environmental conditions. Thirty SCM infected cows with single quarter infection (Group I) and thirty healthy cows (Group II) were included for the present investigation after screening with CMT. Approximately, $80 \mathrm{ml}$ milk from each quarter was collected in sterile vials after cleaning the teat orifice with $70 \%$ ethyl alcohol and discarding few streams of foremilk. The milk samples with negative CMT reaction, $\mathrm{SCC}<3$ lakhs/ $\mathrm{ml}$ and negative for bacterial growth were classified as healthy quarters. Whereas, milk samples with positive CMT reaction (+ or more), SCC> 11 lakhs/ $\mathrm{ml}$ and positive for bacterial growth were classified as SCM infected quarters. The SCC per $\mathrm{ml}$ of milk was determined as per standard method [22]. The isolation of causative organism in collected milk samples was done by spreading $10 \mu \mathrm{l}$ of milk over $5 \%$ bovine blood agar plate and identified on the basis of colony morphology, characteristic hemolytic pattern and Gram's staining [23].

\section{Isolation of milk leukocytes}

The milk leukocytes were isolated from the milk samples as per the standard method [24]. Viability of the cells was checked by trypan blue exclusion technique and the cell suspension was adjusted to $1 \times 10^{8}$ for COX assay and $1 \times 10^{6}$ cells $/ \mathrm{ml}$ in phosphate buffer saline (PBS) for NO production and MPO assay. The whole milk was used for estimation of LP and $\mathrm{C}_{\mathrm{p}}$

\section{COX assay}

The cell pellets $\left(\approx 1 \times 10^{8}\right)$ were sonicated in cold PBS for COX measurement. Total COX activity in the milk cell lysate was estimated by COX activity assay kit as per manufacturer's instruction (Cayman Chemical Company, Ann Arbor, MI).

\section{MPO assay}

The MPO was assayed by using o-dianisidine (Sigma, St. Louis, MO, USA) as electron donor [25] and enzyme concentration was calculated by using molar extinction coefficient for oxidized o-dianisidine. In brief, the test was initiated with adding $0.2 \mathrm{ml}$ of milk leukocyte suspension $\left(1 \times 10^{6}\right.$ cells $\left./ \mathrm{ml}\right)$ to $2.0 \mathrm{ml}$ of substrate solution (0.08 $\mathrm{M} \mathrm{H}_{2} \mathrm{O}_{2}, 0.32 \mathrm{mM}$ o-dianisidine and $0.05 \%$ Triton X-100 in $0.1 \mathrm{M}$ citric acid sodium citrate buffer $(\mathrm{pH} 5.5 \pm 0.1)$ ). The mixture was incubated at room temperature for 1.0 minute and reaction was terminated by adding $2.0 \mathrm{ml}$ of $35 \%$ perchloric acid. Absorbance was read at $560 \mathrm{~nm}$ in spectrophotometer. Since no standard is available, the molar extinction coefficient for oxidized o-dianisidine was assessed with known amounts of glucose oxidase-peroxidase assay and found to be $20,040 \pm 400 \mathrm{~mol}^{-1} \mathrm{dm}^{-1} \mathrm{~cm}^{-1}$.

\section{NO production assay}

NO production in milk leukocytes was measured by nitrate reduction on copper-cadmium alloy ( $\mathrm{Cu}-\mathrm{Cd}$ alloy) followed by colour development with Griess reagent as per the method described earlier [26]. In brief, $100 \mu \mathrm{l}$ of $1 \times 10^{6}$ cells $/ \mathrm{ml}$ stimulated with $25 \mu \mathrm{g}$ of lipopolysaccharide (LPS) was incubated at $37^{\circ} \mathrm{C}$ for 24 hours. After incubation $100 \mu \mathrm{l}$ of pre stimulated cells were suspended in $400 \mu \mathrm{l}$ of carbonate buffer with $150 \mathrm{mg}$ of $\mathrm{Cu}-\mathrm{Cd}$ fillings and again incubated for $1 \mathrm{hr}$ at room temperature with frequent vortexing. The reaction was stopped by adding sodium hydroxide $(\mathrm{NaOH}, 0.35 \mathrm{M})$ and Zinc sulfate
$\left(\mathrm{ZnSO}_{4}, 120 \mathrm{mM}\right)$. Further the mixture was vortexed and centrifuged at $400 \mathrm{~g}$ for 15 minutes. Finally, the Griess reagent was added to the clear supernatant in equal volume. After 10 minute OD was measured at 545 $\mathrm{nm}$ in micro plate reader. The value of NO production was calculated from a standard curve using various concentrations of potassium nitrite.

\section{Estimation of $\mathrm{C}_{\mathrm{p}}$ in milk}

For Cp estimation, milk serum (whey) was prepared at a two-step centrifugation procedure. At first milk samples were centrifuged at $3000 \mathrm{rpm}$ for $10 \mathrm{~min}$ to remove their creams and cells. Samples were then treated with $0.1 \mathrm{M}$ hydrochloric acid at controlled $\mathrm{p}^{\mathrm{H}}$ for $20 \mathrm{~min}$ for casein precipitation. Treated samples were recentrifuged and the supernatants (Whey) were collected. The $C_{p}$ level in milk serum was determined by measuring paraphenylene diamine (PPD) oxidase activity as per method described earlier [27].

\section{Estimation of LP in milk}

The measurement of lactoperoxidase (LP) in milk was performed as per method described earlier [28]. In brief, $1.0 \mathrm{ml}$ milk was taken and diluted to five times in $0.1 \mathrm{M}$ - acetate buffer $\left(\mathrm{p}^{\mathrm{H}} 4.5\right)$. From diluted milk samples, $30 \mu \mathrm{l}$ was rapidly added to $2.95 \mathrm{ml}$ of $1.0 \mathrm{mM}-2,2^{\prime}$-azinodi3-ethylbenzthiazoline-sulphonic acid (ABTS) in acetic buffer in a cuvette. The baseline absorbance at $412 \mathrm{~nm}$ was adjusted to zero before addition of $30 \mu \mathrm{l} 10 \mathrm{mM}$ hydrogen peroxide solution in acetate buffer. The increase in extinction was followed for 5 minutes and units were expressed as the amount of enzyme required to oxidize $1 \mu \mathrm{mol}$ ABTS/ minute. The molar extinction coefficient of ABTS is $32400 \times 10^{3} \mathrm{~mol}$ ${ }^{1} \mathrm{dm}^{-1} \mathrm{~cm}^{-1}$.

\section{Statistical analysis}

Data were analyzed using statistical software package (SPSS Version 10.1, South Asia, and Bangalore, India). Paired sample' $t$ ' test was employed to note the differences of various parameters between milk samples of healthy and SCM infected animals. P $<0.05$ was considered statistically significant. Correlation ( $r$ ) analysis was performed to determine the relationship among SCC and COX, SCC and MPO, SCC and NO, SCC and LP as well as SCC and $\mathrm{C}_{\mathrm{p}}$.

\section{Results}

The mean values of SCC, LP activity, $\mathrm{C}_{\mathrm{p}}$ level of milk, COX, MPO activity, NO production in milk cells between SCM infected (group I) and healthy (group II) quarters were compared and presented in Table 1. The SCC of milk was significantly $(\mathrm{P}<0.05)$ high $\left(11.19 \pm 0.28 \times 10^{5} /\right.$ $\mathrm{ml})$ in SCM infected quarters as compared to healthy quarters $(2.79$ $\pm 0.12 \times 10^{5} / \mathrm{ml}$ ). The organism isolated from 15 milk samples of SCM infected cows were Staphylococcus aureus (33.33\%), Streptococcus agalactiae $(13.33 \%)$, other streptococci $(40.00 \%)$ and Coliform bacilli

Mean \pm standard error $(\mathrm{SE})$
\begin{tabular}{|l|l|l|}
\hline Parameters $(\mathrm{n}=30)$ & Group I $(\mathrm{SCM})$ & Group II (healthy) \\
\hline SCC $\left(\times 10^{5} / \mathrm{ml}\right)$ & $11.19 \pm 0.28^{\mathrm{a}}$ & $2.79 \pm 0.12^{\mathrm{b}}$ \\
\hline COX $(\mathrm{nmoles} / \mathrm{min} / \mathrm{ml})$ & $15.08 \pm 0.61^{\mathrm{a}}$ & $2.41 \pm 0.25^{\mathrm{b}}$ \\
\hline NO $\left(\mu \mathrm{moles} / 1 \times 10^{6} \mathrm{cells} / 24 \mathrm{hrs}\right)$ & $21.55 \pm 1.24^{\mathrm{a}}$ & $9.13 \pm 0.49^{\mathrm{b}}$ \\
\hline Cp $(\mathrm{g} / \mathrm{Liter})$ & $0.93 \pm 0.03^{\mathrm{a}}$ & $0.31 \pm 0.01^{\mathrm{b}}$ \\
\hline MPO $\left(\mu \mathrm{moles} / 10^{6}\right.$ cells $)$ & $6.42 \pm 0.27^{\mathrm{a}}$ & $3.15 \pm 0.21^{\mathrm{b}}$ \\
\hline LP $(\mathrm{u} / \mathrm{ml})$ & $1.59 \pm 0.09^{\mathrm{a}}$ & $0.27 \pm 0.01^{\mathrm{b}}$ \\
\hline
\end{tabular}

*Superscripts in each row $(a, b)$ differ significantly $(p<0.05)$

Table 1: Comparison of SCC, COX activity, NO production, Cp level, MPO activity and LP activity in SCM infected (Gr. I) and healthy (Gr. II) quarters. 
Citation: De UK, Mukherjee R (2011) Potential of Indigenous Enzymatic Activities, Nitric Oxide and Ceruloplasmin in Bovine Milk to Diagnose Subclinical Mastitis. J Veterinar Sci Technol 2:109. doi:10.4172/2157-7579.1000109

(13.33\%). The average LP activity and $\mathrm{C}_{\mathrm{p}}$ level in milk of healthy quarters (group II) were $0.27 \pm 0.01 \mathrm{u} / \mathrm{ml}$ and $0.31 \pm 0.01 \mathrm{~g} /$ liter respectively. The LP and Cp activities were significantly $(\mathrm{P}<0.05)$ increased to 83.01 $\%$ and $66.66 \%$ respectively, in milk samples collected from SCM infected quarters (group I). Similarly, mean values of COX activity in milk cell lysate, MPO activity and NO production in milk cells were $2.41 \pm 0.25 \mathrm{nmol} / \mathrm{min} / \mathrm{ml}, 3.15 \pm 0.21 \mu \mathrm{moles} / 1 \times 10^{6}$ cells and $9.13 \pm$ $0.49 \mu$ moles $/ 1 \times 10^{6}$ cells $/ 24 \mathrm{hrs}$ respectively, in group II healthy quarters. However, the values of COX activity, MPO activity and NO production were significantly $(\mathrm{P}<0.05)$ augmented to $84.01 \%, 50.93 \%$ and $57.63 \%$ respectively, in SCM infected quarters (group I). Pearson's correlation (r) of paired data of individual SCM infected quarters revealed the existence of a significant positive $(\mathrm{P}<0.01)$ correlation between SCC and the values of COX activity $(r=0.647)$, LP activity $(r=0.947)$, MPO activity $(\mathrm{r}=0.905)$ and NO production $(\mathrm{r}=0.855)$ (Figure $1 \mathrm{a}, 1 \mathrm{~b}, 1 \mathrm{c} \&$ 1d). However, no significant correlation between SCC and $C_{p}$ level was observed in milk samples of SCM infected quarters.

\section{Discussion}

The major changes in the udder during mastitis include leaking of ions, proteins and enzymes from the blood into the milk due to an increased permeability and alteration in cellular activity. Elevated SCC in cow milk is a sign of increased immunological activity due to invasion of pathogens, which may result in mastitis. Different factors are responsible for natural defense of mammary gland against invading microorganisms. Inflammatory mediators like prostaglandins and leukotriens exert chemotactic activity of milk leukocytes and enhance the bactericidal activity of phagocytes in dairy cows [2,29]. The key enzymes such as cyclooxygenase play a vital role in prostaglandin synthesis during inflammation. In this present study, COX activity in milk cell lysate was significantly $(\mathrm{P}<0.05)$ high in $\mathrm{SCM}$ infected quarters as compared to healthy quarters. Although clinical investigation does not result in visible signs of inflammatory process in SCM, however, elevated level of COX activity could be a result of inflammation and increased immunological activity of mammary gland. In this study, a statistically positive correlation between SCC and COX activity ( $r$ $=0.647 ; \mathrm{P}<0.01)$ in SCM quarters indicates that the relationship between raised COX activity and inflammation. In this regard, alteration of COX level in milk cells could be used as an alternative diagnostic tool to detect inflammation during SCM. Sarikaya et al. [30] observed increase synthesis of prostaglandin and COX-2 mRNA expression in dairy cows with increased SCC in milk.

Nitric oxide, an important powerful microbial oxidant, plays some role during inflammatory process [31]. Over production of NO has been observed in several inflammatory diseases [32]. The macrophage and epithelial cells of mammary gland produce significant amount of nitric oxide, the inducible NO takes part in the inflammatory process [33]. Moreover, NO stimulates prostaglandin synthesis in macrophages as a result of direct activation of cyclooxygenase activity [34]. Blum et al. [35] indicated a possible clinical relevance of nitric oxide production associated with a rise of intramammary and systemic TNF- $\alpha$ during acute, E. coli mastitis. In the current study, over production of NO in milk samples of SCM infected quarters might be due to activation of COX and TNF- $\alpha$ of milk leukocytes. Several workers found that intramammary infection leads to release of significant amount of NO that closely parallels increases in all classical markers of mastitis such as SCC and NAGase [33,36]. In the present investigation, a positive correlation between SCC and NO $(r=0.855 ; \mathrm{P}<0.01)$ in SCM quarters indicates that the relationship between increased $\mathrm{NO}$ production and inflammation. Therefore, alteration of NO in milk cells could be used
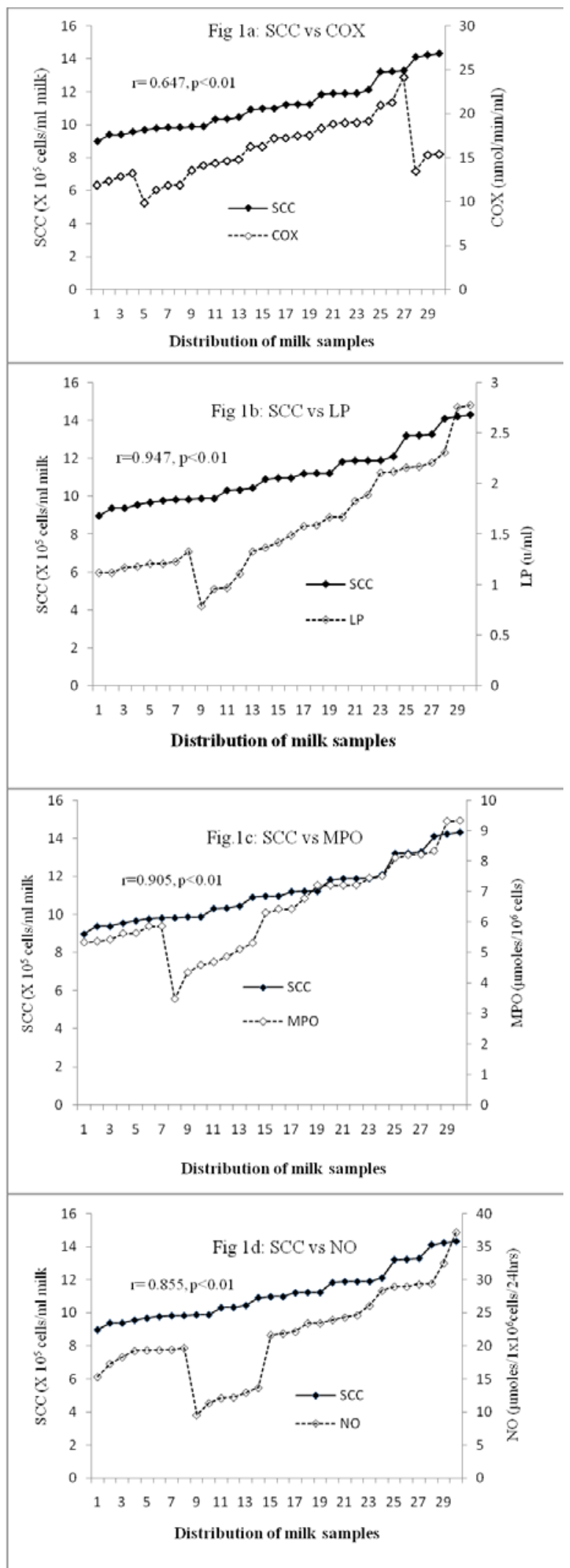

Figure 1: The correlation between SCC and COX activity (1a), SCC and LP activity (2b), SCC and MPO activity (1c) and SCC and NO production (1d) in milk samples with SCM $(P<0.01)$. 
as alternative diagnostic indicator to assess the inflammation during SCM of dairy cows.

Acute phase proteins regulate the immune system and have stimulatory effect on immune response. $\mathrm{Cp}$, an acute phase protein, acts as a peroxidase and it oxidizes ferrous to ferric state. It protects tissues from iron-mediated free radical injury and is involved in various antioxidant and cytoprotective activities [37]. In this study, Cp activity in milk was significantly higher $(p<0.05)$ in SCM infected quarters than healthy ones but there was no significant correlation between SCC and Cp activity in milk. Level of acute phase protein in milk from infected quarters increases due to high permeability of blood milk barrier during episodes of mastitis $[10,12,38]$. It has been reported that determination of $\mathrm{Cp}$ in milk rather than plasma is a suitable indicator for early diagnosis of mastitis in dairy cows [39]. Here, elevated level of $\mathrm{C}_{\mathrm{p}}$ in milk samples of SCM cases suggests an indicator of the mammary gland infection. Since, the activity of $\mathrm{Cp}$ is mainly linked to changes in vascular permeability, biosynthetic, metabolic and catabolic profile of many organs rather than milk cells [40-42], therefore, it may not be expected that the $\mathrm{C}_{\mathrm{p}}$ activity increases with the enhancement of SCC and thus with the occurrence of subclinical mastitis in lactating cows.

Mammary gland infection induces inflammatory reaction which leads to enhancement of SCC and activation of bacteristatic enzymes in milk. Neutrophils are the predominant cell type found in the mammary gland during inflammation and important for udder defense mechanism. The MPO, a lysosomal enzyme of neutrophilic granules, is a constituent of oxygen dependent antimicrobial activity of leukocytes [15]. Similarly, LP, the predominant antioxidant enzyme synthesized by polymorphonuclear leukocytes, responsible for a potent non-specific bacteristatic or bactericidal activity in milk $[43,44]$. In the current study, MPO and LP activity were significantly $(\mathrm{p}<0.05)$ high in milk samples of SCM infected quarters compared to healthy quarters. A pronounced positive correlation was also observed between SCC with MPO activity $(\mathrm{r}=0.905 ; \mathrm{P}<0.01)$ as well as with LP activity $(\mathrm{r}=0.947 ; \mathrm{P}<0.01)$ in milk of SCM infected quarters. Several workers demonstrated augmented MPO activity in mammary tissue, milk and blood cells during mastitis in different animal species [4547]. Similarly, LP is increased in mastitis milk of cows and goat and is being established a positive correlation between enzyme activity and number of SCC $[19,48]$. Since the number of somatic cells in milk increases in SCM and since these enzymes are synthesized mainly by milk leukocytes, therefore, it is logical to expect that the MPO and LP activity increase with the enhancement of SCC during SCM. Further, the biological role of both the enzymes is to protect the mammary gland from infection, and suggests its involvement in the natural host defence system against invading pathogens.

In conclusion, SCM augments COX, LP, MPO activities and NO production in milk cells and $\mathrm{C}_{\mathrm{p}}$ activity in whole milk. A significant correlation between SCC with COX, LP, MPO activities and NO production during SCM in lactating cows suggests that measurement of these parameters could be used as alternative diagnostic tool for detection of SCM in cows.

\section{Acknowledgement}

The authors thank the Director, IVRI, and Head, Division of Medicine, for providing necessary facilities.

\section{References}

1. Sharma N, Singh NK, Bhadwal MS (2011) Relationship of Somatic Cell Count and Mastitis: An Overview Asian-Australasian. Journal of Animal Sciences 24: $429-438$.
2. Persson K, Larsson I, Hallen sandgren C (1993) Effects of certain inflammatory mediators on bovine neutrophil migration in vivo and in vitro. Vet Immunol Immunopathol 37: 99-112.

3. Schmitz S, Pfaffl MW, Meyer HH , Bruckmaier RM (2004) Short-term changes of mRNA expression of various inflammatory factors and milk proteins in mammary tissue during LPS-induced mastitis. Domest Anim Endocrinol 26: 111-126.

4. Boulanger V, Bouchard L, Zhao X , Lacasse $P$ (2001) Induction of nitric oxide production by bovine mammary epithelial cells and blood leukocytes. J Dairy Sci 84: 1430-1437

5. Komine K, Kuroishi T, Komine Y, Watanabe K, Kobayashi J et al. (2004) Induction of nitric oxide production mediated by tumor necrosis factor alpha on staphylococcal enterotoxin C-stimulated bovine mammary gland cells. Clin Diagn Lab Immunol 11: 203-210.

6. Osman KM, El-Enbaawy MI, Ezzeldin NA, Hussein HM (2010) Nitric oxide and lysozyme production as an impact to Clostridium perfringens mastitis. Comp Immunol Microbiol Infect Dis 33: 505-511.

7. Osman KM, Hassan HM, Ibrahim IM, Mikhail MM (2010) The impact of staphylococcal mastitis on the level of milk IL-6, lysozyme and nitric oxide. Comp Immunol Microbiol Infect Dis 33: 85-93.

8. Petersen HH, Nielsen JP, Heegaard PM (2004) Application of acute phase protein measurements in veterinary clinical chemistry. Vet Res 35: 163-187.

9. Haghkhah M, Nazifi S, Jahromi AG (2010) Evaluation of milk haptoglobin and amyloid A in high producing dairy cattle with clinical and subclinical mastitis in Shiraz. Comparative Clinical Pathology 19: 547-552.

10. Nielsen BH, Jacobsen S, Andersen PH, Niewold TA, Heegaard PM (2004) Acute phase protein concentrations in serum and milk from healthy cows, cows with clinical mastitis and cows with extramammary inflammatory conditions. Vet Rec 154: 361-365.

11. Conner JG, Eckersall PD, Doherty M, Douglas TA (1986) Acute phase response and mastitis in the cow. Res Vet Sci 41: 126-128.

12. Singh SV , Pachauri SP (2002) Acute phase proteins in bovine mastitis. Indian journal of animal sciences 72: 20-22.

13. Korhonen $\mathrm{H}$, Kaartinen $\mathrm{L}$ (1995) Changes in the composition of milk induced by mastitis. In: Sandholm, M., Honkanen-Buzalski,T., Kaartinen, L., Pyorala, S. (Eds.), The Bovine Udder and Mastitis. University of Helsinki, Faculty of Veterinary Medicine, Helsinki, pp. 76-82.

14. Cooray R , Bjorck L (1995) Bactericidal activity of the bovine myeloperoxidase system against bacteria associated with mastitis. Vet Microbiol 46: 427-434

15. Cooray RA, Petersson CG, Holmberg O (1993) Isolation and purification of bovine myeloperoxidase from neutrophil granules. Vet Immunol Immunopathol 38: 261-272.

16. Bobowiec R, Wessely-Szponder J , Hola P (2009) Crosstalk between coagulation and inflammation in mastitis and metritis in dairy cows. Acta Vet Hung 57: 283-293.

17. Mukherjee R, De UK, Ram GC (2010) Evaluation of mammary gland immunity and therapeutic potential of Tinospora cordifolia against bovine subclinical mastitis. Trop Anim Health and Prod 42: 645-651.

18. Moatsou G (2010) Indigenous enzymatic activities in ovine and caprine milks International Journal of Dairy Technology 63: 16-31.

19. Andrei S, Pintea A, Groza I, Bogdan L, Cipue S et al. (2009) Milk antioxidant enzymes activity in cows with subclinical mastitis. Lucrari Stiintifice Medicina,University de Stiinte Agricole si Medicina Veterinara "Ion-Ionescu-dela-Brad"-lasi 52:1-6.

20. Hillerton JE (1999) Redefining mastitis based on somatic cell count. Bulletin FIL-IDF 345: 4-6.

21. Nielen M, Schukken YH, Brand A, Deluyker HA, Maatje K (1995) Detection of subclinical mastitis from on-line milking parlor data. J Dairy Sci 78: 1039-1049.

22. Schalm OW, Carrol E J, Jain NC (1971) Bovine Mastitis. Ed Lea and Febiger, Philadelphia, pp. 128-129

23. Griffin TK, Dodd FH, Neave K, Westgarth DR, Kingwil RG et al. (1977) A method for diagnosing intramammary infection in dairy cows for large experiments. $J$ Dairy Res 44: 25-45. 
Citation: De UK, Mukherjee R (2011) Potential of Indigenous Enzymatic Activities, Nitric Oxide and Ceruloplasmin in Bovine Milk to Diagnose Subclinical Mastitis. J Veterinar Sci Technol 2:109. doi:10.4172/2157-7579.1000109

Page 5 of 5

24. Daley MJ, Oldham ER, Williams TJ, Coyle PA (1991) Quantitative and qualitative properties of host PMN cells during experimentally induced staphylococcus aureus mastitis in cows. Am J Vet Res 52: 474-479.

25. Bretz U, Baggiolini M (1974) Biochemical and morphological characterization of azurophilic and specific granules of human neutrophilic polymorphonuclear leukocytes. J Cellular Biol 63: 251-269.

26. Sastry KV, Moudgal RP, Mohan J, Tyagi JS, Rao GS (2002) Spectrophotometric determination of serum nitrite and nitrate by copper-cadmium alloy. Anal Biochem 306: 79-82.

27. Sunderman SW Jr, Nomoto S (1970) Measurement of human serum ceruloplasmin by its p-phenylenediamine oxidase activity. Clin Chem 16: $903-$ 910

28. Marshall VM, Cole WM, Bramley AJ (1986) Influence of lactoperoxidase system on susceptibility of the udder to Streptococcus uberis infection. J Dairy Res 53: 507-514

29. Heidel JR, Taylor SM, Laegreid WW, Silflow RM, Liggitt HD et al. (1989) In vivo chemotaxis of bovine neutrophils induced by 5 -lipoxygenase metabolites of arachidonic and eicopentaenoic acid. Am J Pathol 134: 671-678.

30. Sarikaya H, Schlamberger G, Meyer HH , Brucmaier RM (2006) Leukocyte populations and mRNA expression of inflammatory factors in quarter milk fractions at different somatic cell score levels in dairy cows. J Dairy Sci 89: 2479-2486.

31. McCall T, Vallance $P$ (1992) Nitric oxide takes centre-stage with newly defined roles. Trends Pharmacol Sci 13: 1-6

32. Dawson TM, Dawson VL (1995) Nitric Oxide: Actions and Pathological Roles. Neuroscientist 1: 7-18

33. Bouchard L, Blais S, Debrosiers C, Zhao X, Lacasse P (1999) Nitric oxide production during endotoxin-induced mastitis in the cows. J Dairy Sci 82: 25742581

34. Landino LM, Crews BC, Timmons MD, Morrow JD, Marnett, LJ (1996) Peroxynitrite, the coupling product of nitric oxide and superoxide, activates prostaglandin biosynthesis. Proc Natl Acad Science USA 93: 15069-15074.

35. Blum JW, Dosogne H, Hoeben D, Vangroenweghe F, Hammon HM, Bruckmaier RM , Burvenich C (2000) Tumor necrosis factor-alpha and nitrite/ nitrate responses during acute mastitis induced by Escherichia coli infection and endotoxin in dairy cows. Domest Anim Endocrinol 19: 223-235.

36. Atakisi O, Oral H, Atakisi E, Merhan O, Metin Pancarci S et al. (2010) Subclinical mastitis causes alterations in nitric oxide, total oxidant and antioxidant capacity in cow milk. Res Vet Sci 89: 10-13.

37. Inoue K, Akaike T, Miyamoto Y, Okamoto T, Sawa T et al. (1999) Nitrosothio formation catalyzed by ceruloplasmin. Implication for cytoprotective mechanism in vivo. J Biol Chem 274: 27069-27075.

38. Szczubia M, Dabrowski R, Kankofer M, Bochniarz M, Albera E (2008) Concentration of serum amyloid $A$ and activity of ceruloplasmin in milk from cows with clinical and subclinical mastitis. Bulletin of the Veterinary Institute in Puawy 52: 391-395.

39. Tabrizi AD, Batavani RA, Rezaei SA Ahmadi M (2008) Fibrinogen and ceruloplasmin in plasma and milk from dairy cows with subclinical and clinical mastitis. Pak J Biol Sci 11: 571-576.

40. Steel DM, Whitehead AS (1994) The major acute phase reactants: C-reactive protein, serum amyloid $\mathrm{P}$ component and serum amyloid $\mathrm{A}$ protein. Immuno Today 1: 81-88.

41. Pan Y, Katula K, Failla ML (1996) Expression of ceruloplasmin gene in human and rat lymphocytes. Biochim Biophys Acta 1307: 233-238.

42. Mazumder B, Mukhopadhyay CK, Prok A, Cathcart MK, Fox PL (1997) Induction of ceruloplasmin synthesis by IFN-gamma in human monocytic cells J Immunol 159: 1938-1944.

43. Korhonen $\mathrm{H}$ (1980) Potential role of the lactoperoxidase system (LP/SCN-/ $\mathrm{H}_{2} \mathrm{O}_{2}$ ) in mastitis resistance. In: Bassalik-Chabielska, L., Ryniewicz, Z. (Eds.), Proceedings of International Conference on Resistant Factors and Genetic Aspects of Mastitis Control. Jablonna, Poland, 2-5 October, pp. 421-438.

44. Seifu E, Buys EM, Donkin EF , Petzer IM (2004) Antibacterial activity of the lactoperoxidase system against food-borne pathogens in Saanen and South African Indigenous goat milk. Food Control 15: 447-452.

45. Sladek Z, Rysanek D, Ryznarova H , Faldyna M (2005) Neutrophil apoptosis during experimentally induced Staphylococcus aureus mastitis. Vet Res 36 629-643.

46. Ting Y, JinFeng M, SiXiang Z, WeiHua C , GenLin W (2006) The changes of enzymes and cytokines in milk and blood during experimental mastitis in goat. Journal of Yangzhou University Agricultural and Life Sciences 27: 52-55.

47. Gu BB, Miao JF, Zhu YM, Deng YE, Zou SX (2009) Protective effect of retinoid against endotoxin-induced mastitis in rats. Inflamm Res 58: 81-88.

48. Seifu E, Donkin EF, Elna M, Buys EM (2007) Potential of lactoperoxidase to diagnose subclinical mastitis in goats. Small Ruminant Research 69: 154-158. 